DOI: $10.12797 /$ Politeja.12.2015.39.02

Tomasz TULEJSKI

Uniwersytet Łódzki

ttulejski@tlen.pl

\title{
DOKTRYNA WŁADZY MONARSZEJ JAKUBA VI (I) STUARTA
}

\section{ABSTRACT James I Stuart's theory of the divine right of kings}

The author presents King James I Stuart's theory of the divine right of kings as the modification of Bodin's concept of the sovereignty. According to King James, a monarch is subjected to no earthly authority, as he derives his right to rule directly from the will of God. The king is thus not a subject to the will of his people, the aristocracy, or any other estate of the realm, including the Church. This doctrine implies that any attempt to depose a king or to restrict his power is contrary to the will of God and may constitute treason. The author argues, that the theory of the divine right of kings is rooted in the medieval idea that God had bestowed earthly power to the king, just as He had given spiritual power and authority to the Church, centering on a pope and in this way in protestant kingdoms may justifies the king's absolute authority in both political and spiritual matters. The author points out that it is contrary to Bodin's theory of sovereignty and he argues that King James' general statements of divine right should not be read as claims about specific royal powers in any particular kingdom. Unlike the theorists of absolutism, King James thus believed the king to be bound to exercise his authority through defined constitutional channels. Such a requirement went beyond that expected of the absolute monarch, who was to rule well if he were to avoid the charge of tyranny. Finally the author argues, that King James' theory of power is the attempt of the restoration of Christian uniformity and of the re-Christianization of Bodin's concept of the sovereignty.

Keywords: James I, divine right of kings

Słowa kluczowe: Jakub I, boskie prawo królów 
The State of Monarchie is the supremest thing upon earth:

For Kings are not onely Gods Lieutenants upon earth, and sit upon God's throne, but even by God himselfe they are called Gods. James (VI) I Stuart, Speech of 1609

\author{
Not all the water in the rough rude sea \\ Can wash the balm off from an anointed king; \\ The breath of worldly men cannot depose \\ The deputy elected by the Lord.
}

William Shakespeare, Richard II

\title{
WPROWADZENIE
}

Jakub I (VI) Stuart jest bez wątpienia postacią wyjątkową wśród władców Anglii i Szkocji. Choć jego poprzednikom zdarzało się chwytać za pióra, czasem z godnym uwagi efektem, to ich dokonania na polu literatury nie przetrwały próby czasu i mogą być dzisiaj jedynie ciekawostką zaprzątającą uwagę ich biografów. Tymczasem Jakub, który dość wcześnie zdał sobie sprawę z pośledniości swego talentu poetyckiego, całą niemal aktywność literacką skupił na problematyce, która na przełomie XVI i XVII wieku rozpalała do czerwoności umysły wszystkich uczestników toczącej się w całej Europie debaty politycznej. Po rozpadzie średniowiecznej Christianitas i wybuchu reformacji po raz kolejny bowiem zadano sobie fundamentalne pytania o naturę władzy, jej legitymację, zakres władzy monarszej czy rolę Kościoła w nowej rzeczywistości społecznej, politycznej i religijnej. Udział Jakuba w tej dyskusji nie miał przy tym charakteru przyczynkarskiego. Wszechstronne wykształcenie ${ }^{1}$, którym z dumą się szczycił, i silne intelektualne oddziaływanie jego dokonań na polu filozofii politycznej, każą patrzeć na nie już nie jak na ciekawostkę, lecz niebywale istotny głos $\mathrm{w}$ debacie oraz koherentną wizję porządku politycznego, społecznego i religijnego. Boskie prawo królów nie było bowiem, jak wykazał w swej klasycznej pracy John Neville Figgis, wylącznie zbiorem zabawnych propozycji przewrotnie gtoszonych przez stużalczy Kościót ${ }^{2}$, lecz sięgająca głęboko średniowiecznych korzeni ${ }^{3}$ ideą, która dostosowała siatkę pojęciową przemijającej epoki do wyzwań, jakie niosła z sobą reformacja. W tym kontekście warto pochylić się nad argumentem króla Szkocji i Anglii. Choć dopiero starcie następcy Elżbiety I z angielskim Parlamentem uczyniło z Jakuba postać znaną i rozpoznawalną wśród badaczy idei, to zrąb argumentacji na rzecz boskiego prawa

1 M. Lee Jr., Great Britain's Solomon. James VI and I in His Three Kingdoms, Urbana 1990, s. 32.

2 J.N. Figgis, The Theory of the Divine Right of Kings, Cambridge 1896, s. 254, Cambridge Historical Essays, nr 9.

3 Zob. W.H. Greenleaf, James I and the Divine Right of Kings', „Political Studies” 1957, Vol. 5, nr 1, s. 36-48; F. Oakley, Jacobean Political Theology. The Absolute and Ordinary Powers of the King, "Journal of the History of Ideas" 1968, Vol. 29, nr 3, s. 323-346. 
królów ${ }^{4}$ sformułowany został już podczas jego panowania jako Jakuba VI na tronie szkoc-

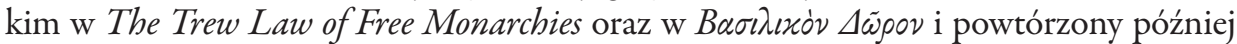
w jego mowach do angielskiego Parlamentu. Argumentacja ta, czerpiąca z wielu inspiracji, stanowi najpełniejsze chyba, obok powstałego później Patriarchy Roberta Filmera, uzasadnienie boskiego prawa królów skierowane przeciwko radykalnym i w swej wymowie rewolucyjnym tezom formułowanym w niektórych kręgach protestanckich. Stąd moim celem będzie wskazanie Jakubowych inspiracji i wniosków, które z nich wywiódł, udowadniając swą władzę jako monarchy. Przy okazji też postaram się wykazać, iż jego wizja władzy, mimo licznych powierzchownych podobieństw, różni się od sformułowanego wcześniej uzasadnienia absolutyzmu autorstwa Jeana Bodina, którego Jakub niebywale cenił5. Stąd na początku wywodu zaprezentuję zarys radykalnych koncepcji wymierzonych przeciwko władzy absolutnej, jakie powstały w kręgach radykalnych kalwinistów. Następnie przejdę do odpowiedzi udzielonej im przez Jakuba. Rozpocznę od starotestamentowego uzasadnienia władzy absolutnej przytaczanego przez króla Szkocji. W dalszej części odwołam się do przywoływanych przez niego argumentów natury historycznej, a następnie przejdę do sformułowanego przez niego wzorca władcy chrześcijańskiego. W końcu spróbuję zestawić wnioski, do jakich doszedł, z tymi, które odnaleźć można w Sześciu księgach o Rzeczypospolitej.

Ponieważ przed wiekiem XVI nie istniała w Szkocji prawie wcale tradycja politycznego teoretyzowania, Jakub musiał niemal samodzielnie stworzyć doktrynalne fundamenty swojej władzy ${ }^{6}$. Podobnie jak dla przeważającej części uczestników XVI- i XVII-wiecznej debaty najważniejszym punktem odniesienia było dla niego Pismo Święte traktowane nie tylko, co oczywiste, jako źródło prawd teologicznych, ale także jako podręcznik polityki, zwłaszcza w kręgach protestanckich. Ten najwyższy autorytet, utożsamiany z wolą samego Stwórcy, przesądzać miał o prawdziwości lub fałszywości wszystkich politycznych hipotez. Zwłaszcza dla radykalnych protestantów Biblia była kluczem, który dać może odpowiedź na problemy czasów współczesnych ${ }^{7}$. Szczególnie szkoccy, a w ślad za nimi angielscy kalwini wyprowadzili z niej przy tym radykalne przesłanie polityczne wymierzone we władzę królewską.

Jeden z najbardziej prominentnych przedstawicieli radykalnej szkockiej reformacji - John Knox - z autorytetu Biblii wywiódł prawo oporu wobec tyrańskiej władzy,

Lecz nie na rzecz monarszego absolutyzmu w wersji nowożytnej, o czym mowa w końcowej części wywodu.

5 J. Wormald, James VI and I, „Basilikon Doron” and "The Trew Law of Free Monarchies”. The Scottish Context and the English Translation, [w:] The Mental World of the Jacobean Court, red. L.L. Peck, Cambridge-New York 1991, s. 43.

6 P. Croft, King James, New York 2003, s. 132.

7 C. Hill, The World Turned Upside Down. Radical Ideas during the English Revolution, London 1973, s. 75 . 
przekonując, że choć każda władza pochodzi od Boga, to jest scedowana nie tylko na króla, lecz także na jego urzędników. Źródłem tej ostatniej, podobnie jak królewskiej, jest wola Stwórcy i podobnie jak on urzędnicy mają obowiązek zreformowania religii zgodnie z prawem Bożym. W Szkocji rolę tę według Knoxa powinna przejąć szlachta, która posiada legalnq wtadzęustanowiona przez Boga ${ }^{8}$, by ochraniali niewinnych $i$ karali ztoczyńnców ${ }^{9}$. Zatem na równi z księciem dzierży ona miecz sprawiedliwości i włada nim nawet, gdy nie czyni tego monarcha. Książęta i urzędnicy państwowi są bowiem powołani nie po to, jak przekonuje Knox, by sprawować władzę tyrańską nad ludem, lecz Bóg ustanowił ich, aby dbali o jego dobro i pomyślność. Gdy więc władca sprzeniewierzy się zadaniu, które powierzył mu sam Stwórca, gdy zwalcza prawdziwą religię, działa przeciwko bożej chwale i swoim współbraciom, jego działania tracą boską sankcję, zwalniając równocześnie poddanych $\mathrm{z}$ obowiązku posłuszeństwa ${ }^{10}$. W sytuacji takiej niżsi urzędnicy bronić muszą przed wściektościa tyranów ${ }^{11}$ Bożego prawa, które nakazuje równocześnie wypowiedzenie posłuszeństwa i przeciwstawienie się bezbożnemu władcy ${ }^{12}$.

Uzasadnienia prawa oporu Knox wzmacnia jeszcze, doszukując się jego genezy w starotestamentowym Przymierzu (Covenant), jakie Bóg zawarł z narodem wybranym $^{13}$. Przekonywał bowiem, że Anglicy i Szkoci to narody, które zawarły przymierze z Bogiem, więc władcy ich są zobowiązani rządzić nimi zgodnie z Bożą wolą i popierać prawdziwą wiarę ${ }^{14}$. Zatem to, co w Biblii odnosi się do problematyki religijnej, przenosi Knox na płaszczyznę polityczną. Wspólnota wiernych bowiem w jego argumentacji utożsamiona zostaje ze wspólnotą państwową. Zabieg ten powoduje, że przyjmuje ona na siebie zobowiązanie zapewnienia pobożnych rządów i staje się wrogiem każdego, kto wzbudza Boży gniew. Stąd każdy członek wspólnoty zobowiązany zostaje do oporu i obalenia tyrańskich władców. Bezpośrednia boska sankcja sprawia przy tym, że jest to nie tylko uprawnienie, lecz święty obowiązek ${ }^{15}$, który spoczywa na całym ludzie bożym. Nie każdy zatem władca posiada boską legitymację, ale boską mocą obdarzona jest wspólnota, która, będąc zbrojnym ramieniem Stwórcy, powołana jest do zapewnienia panowania na ziemi prawdziwej wiary i bożego porządku.

Radykalizm ten odróżnia się zatem od powściągliwości, jaka cechowała na przykład Kalwina, który nie godził się, by przyznać prawo oporu całej wspólnocie, nie mó-

8 J. Knox, On Rebellion, red. R.A. Mason, Cambridge-New York 1994, s. 72, Cambridge Texts in the History of Political Thought.

9 Tamże, s. 85.

10 Tenże, History of the Reformation in Scotland, Glasgow 1841, s. 203-205.

11 Tenże, On Rebellion, s. 102.

12 T. M'Crie, John Knox. Containing Illustrations of the History of the Reformation in Scotland, Edinburgh 1831, s. 123-124.

13 D.G. Mullan, Scottish Puritanism, 1590-1638, Oxford-New York 2000, s. 177-180.

14 W. Stanford Reid, John Knox. The First of the Monarchomachs?, [w:] The Covenant Connection. From Federal Theology to Modern Federalism, red. D.J. Elazar, J. Kincaid, Lanham 2000, s. 122.

15 Tamże, s. 127. 
wiąc już o jej indywidualnych członkach. Takich wątpliwości nie miał także rówieśnik Knoxa - angielski duchowny John Ponet, który dowodził, że opór jest kwestią rozstrzyganą w sumieniu każdego człowieka, który jako jednostka może przeciwstawić się tyranowi, posuwając się nawet do tyranobójstwa ${ }^{16}$. Dla tego radykalnego purytanina władza absolutna należy bowiem tylko do Boga i żaden ziemski władca nie może jej uzurpować. Tak jak wszyscy podlega bowiem prawu boskiemu i prawu natury oraz zwyczajom i prawom królestwa, które wyznaczają granice jego władzy. Jeśli więc władca sięga do tyrańskich praktyk, to przestaje być osobą publiczną, stając się osobą prywatną i wobec tego jego poddani mają pełne prawo do czynnej obrony nawet za pomocą miecza. Książę taki tracił bowiem, poprzez własne działania, szczególną pozycję we wspólnocie, poddani mogą zatem ukarać go za sprzeniewierzenie się roli, jaka została mu powierzona.

U Poneta boskie pochodzenie władzy współistnieje z wywiedzioną z Covenant zgodą poddanych. Stąd władca jest powołany po to, by służył wspólnocie, ochraniał ją i dbał o jej dobro. Królowie, ksiązęta i naczelnicy wspólnot nie maja, i nie można tak twierdzić, absolutnej wtadzy - pisał w A Short Treatise on Political Power - lecz celem ich wtadzy jest wspieranie sprawiedliwości, obrona niewinnych $i$ karanie $z$ tych ${ }^{17} . \mathrm{Z}$ dobrego wykonywania tych zadań władca czerpie swą legitymację, oceny zaś dokonuje nie tylko Bóg w życiu pośmiertnym, lecz tu na ziemi także poddani ${ }^{18}$.

Identyczną niemal argumentację znaleźć można u Christophera Goldmana - przyjaciela Knoxa, który gościł go podczas jego wygnania w Szkocji. W jego opinii tylko lud boży, obdarzony cnotą poprzez swoje przymierze z Bogiem, może podjąć działania w celu ukarania władcy, który zdradził swe obowiązki. W ten sposób Goldman wykracza daleko poza argumentację formułowaną przez kontynentalnych protestantów, chociażby w Vindiciae contra tyrannos, dając tym samym uzasadnienie powszechnej rewolucji przeciwko bezbożnemu władcy ${ }^{19}$.

Najbardziej prominentnym przedstawicielem antyabsolutystycznego nurtu w myśli szkockiej był jednak George Buchanan. Warto przywołać tę postać także z tego powodu, że to właśnie on był paradoksalnie wychowawcą młodego Jakuba. Argumentując $\mathrm{w}$ arystotelesowsko-cycerońskim ${ }^{20}$ duchu, przekonywał, że powstanie wspólnoty podyktowane jest koniecznością zaspokojenia przez jednostki ich naturalnych potrzeb. Dochodzi do tego w wyniku spontanicznej (a nie kontraktualnej) aktualizacji przyrodzonego instynktu społecznego i realizacji zaszczepionych w duszy każdego przez

16 Introduction, [w:] Puritan Political Ideas, 1558-1794, red. E.S. Morgan, Indianapolis 2003, s. XLV.

17 J. Ponet, A Short Treatise on Political Power, and of the True Obedience which Subjects our to Kings and Other Civil Governors, with an Exhortation to All True and Natural English Men (reprint), New York 1972, s. 39.

18 S. Alford, A Politics of Emergency in the Reign of Elizabeth I, [w:] English Radicalism, 1550-1850, red. G. Burgess, M. Festenstein, Cambridge-New York 2007, s. 19.

19 Q. Skinner, The Foundations of Modern Political Thought, Vol. 2: The Age of Reformation, Cambridge 1978, s. 234-235.

20 J.H.M. Salmon, Renaissance and Revolt. Essays in the Intellectual and Social History of Early Modern France, Cambridge 2003, s. 141. 
Boga zasad prawa naturalnego ${ }^{21}$. Ludzie pragną i potrzebują władzy jako środka zabezpieczenia korzyści wynikających ze wspólnego bytowania oraz egzekwowania sprawiedliwości, jako rzeczy niezbędnej dla utrzymania i ochrony utworzonego przez nich społeczeństwa.

Konsekwencją przyjęcia cycerońskiej maksymy salus poluli suprema lex jest dla niego służebny charakter władzy politycznej, którą jej piastun otrzymuje wprost z rąk ludu. Samo prawo natury wskazuje więc, że suwerenność spoczywa w ludzie, który określa i legitymizuje formę rządu i rząd poprzez swą zgodę ${ }^{22}$. Naturalna ułomność ludzkiej natury sprawia równocześnie, że władza, jaką obdarzeni są władcy, nie może być absolutna, stąd jedyną drogą ochrony interesu społeczności musi być jej ograniczenie i poddanie rygorom prawa. Ale poniewaz - pisze Buchanan - stan ludzkich spraw ma, zgodnie z postępem każdego stworzenia, stata tendencje do degeneracji, urząd królewski, który pierwotnie ustanowiony zostat dla publicznej użyteczności, degenerowat się stopniowo do nieudolnej tyranii. Ponieważ, odkąd królowie nie przestrzegali żadnych praw, ale zaspokajali swe kapryśne namiętności i ujrzeli swa wtadze jako nieograniczona i nieumiarkowana, nie znajdowali żadnych granic dla swych żadz $i$ byli powodowani tak swa stronniczościa, tak nienawiścia, jak i swym prywatnym interesem, ich despotyczna bezczelność pobudzita powszechne pragnienie prawa. Z tego powodu zostaty przez lud ustanowione statuty $i$ królowie w swych sędziowskich decyzjach zostali zobowiązani, by przyjać nie to, co dyktowaty ich wtasne rozwiazte fantazje, ale to, co uświęcity prawa sankcjonowane przez lud. Ludzie bowiem zostali nauczeni przez wiele doświadczeń, że dużo bezpieczniej ufać wolnościom chronionym przez prawo niźli królów ${ }^{23}$.

Oznacza to ni mniej, ni więcej, że władca nie stoi ponad prawem i nie jest zewnętrzny wobec wspólnoty politycznej. Przeciwnie, Buchanan postrzega go jedynie jako delegata ludu lub jego przedstawicieli sprawującego władzę o zakresie określonym przez sam lud. Równocześnie to on sam, najlepiej znający swój interes i potrzeby, określa treść prawa, czyniąc z władcy jedynie wykonawcę swej woli, pozostawiając w swych rękach najwyższe zwierzchnictwo. Taka utrzymana w granicach prawa władza królewska nie doznaje jednak, zdaniem Buchanana, ograniczenia swej wolności, potęgi i majestatu, bowiem stoi za nią zgoda, siła i miłość ludu²4. To one, a nie terror i przemoc, czyniąjedynie wtadcęniezwyciężonym ${ }^{25}$.

21 B. Szlachta, Konstytucjonalizm czy absolutyzm? Szkice z francuskiej myśli politycznej XVI wieku, Kraków 2005, s. 428, Biblioteka Myśli Politycznej - Ośrodek Myśli Politycznej, 43.

22 R.A. Mason, Introduction, [w:] G. Buchanan, A Dialogue on the Law of Kingship Among the Scots. De Jure Regni Apud Scotos Dialogus, przeł. i red. M.S. Smith, R.A. Mason, Edinburgh 2006, St. Andrews Studies in Reformation History, s. 12.

23 G. Buchanan, De Jure Regni Apud Scotos, or, A Dialogue, Concerning the Due Privilege of Government, in the Kingdom of Scotland, Betwixt George Buchanan and Thomas Maitland, Philadephia 1766, s. 13.

24 J.B. Scott, The Catholic Conception of International Law. Francisco de Vitoria, Founder of the Modern Law of Nations, Francisco Suárez, Founder of the Modern Philosophy of Law in General and in Particular of the Law of Nations. A Critical Examination and a Justified Appreciation, Washington D.C. 1934, s. 359 .

25 G. Buchanan, De Jure..., s. 42. 
Perspektywa taka pozwala Buchananowi na sformułowanie koncepcji tyranii oraz towarzyszącej jej idei oporu i tyranobójstwa. Posłuszeństwo wobec władzy ma bowiem u niego charakter warunkowy i jest funkcją troski o dobro wspólnoty i realizacji woli ludu jako zbiorowego zwierzchnika. Klasyczne kryterium celu władzy pozwala mu na odróżnienie króla władającego zgodnie z prawem dla dobra poddanych od tyrana ${ }^{26}$. Władca, który - pomimo upomnień - miast stać na straży sprawiedliwości i dobra ludu, sprzeniewierza się swemu posłannictwu, gwałci prawa i instytucje swego królestwa, sprzeciwia się woli i interesowi zbiorowego zwierzchnika, staje się pospolitym przestępcą, wrogiem publicznym ${ }^{27}$, przeciwnikiem nie mniejszym niż zewnętrzny agresor, wobec którego opór jest nie tylko prawem, lecz obowiązkiem poddanych. A kiedy ze sprawiedliwej przyczyny raz zostata ogtoszona wojna przeciwko otwartemu wrogowi, wtedy nie tylko lud, ale kazda osoba ma prawo zabić tego wroga ${ }^{28}$, który jest nie tylko wrogiem ludu, ale i samego Stwórcy. Mamy tu zatem do czynienia z najdalej idącą koncepcją prawa oporu, uzasadniającą i usprawiedliwiającą tyranobójstwo.

\section{II}

Zapoznanie się przez młodego Jakuba z koncepcjami swego nauczyciela (choć wiele $\mathrm{z}$ nich ukazało się drukiem dopiero w okresie jego rządów) i pokrewnych mu ideowo kompanionów ${ }^{29}$ określiło bezkompromisowość jego odpowiedzi i z pewnością odcisnęło niezatarte piętno na jego refleksji politycznej, tak że po latach, w napisanym dla syna

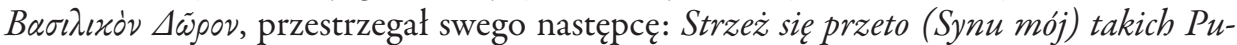
rytan, istnych Kościota i rzeczpospolitej szkodników, których żadna nagroda nie zobowiazuje, ni przysiega, ni obietnica nie przymusza, buntem i oszczerstwem jedynie tchnacych, aspirujacych bez umiaru, pomstujacych bez powodu i wtasna swa wyobraźnię (bez żadnego w stowie oparcia) wyktadnia sumienia swego czyniacych. Przed Bogiem ci zaręczam najwyższym, a ponieważ tekst ten niczym Testament jest mój, ktamać się w nim nie godzi, że nigdy ze strony żadnego ze ztodziei, co z Pogórza lub Pogranicza się wywodza, większej nie zaznasz niewdzięczności, więcej ktamstw i krzywoprzysięstw nikczemnych, niźli z tych wtaśnie fanatycznych ludzi strony ${ }^{30}$. Radykalizm oponentów Jakuba, wprost podważających fundamenty władzy monarszej i jej pochodzący od Boga ekskluzywizm, określił ton odpowiedzi sformułowanej przez monarchę, jeszcze jako króla Szkocji, borykające-

26 R.A. Mason, Introduction, s. 12.

27 G. Buchanan, De Jure..., s. 45.

28 Tamże, s. 66.

29 Zob. R.A. Mason, George Buchanan, James VI and the Presbyterians, [w:] Scots and Britons. Scottish Political Thought and the Union of 1603, red. R.A. Mason, Cambridge 1994, s. 112-137; I.D. McFarlane, Buchanan, London 1981, s. 445-450; C. Bingham, The Making of a King. The Early Years of James VI and I, Garden City, N.Y. 1968, s. 51-55.

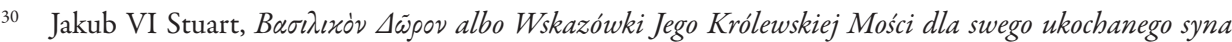
Henryka, księcia, wstęp, przel. i oprac. M. Misztal, Kraków 2006, s. 91, Literatura Parenetyczna przez Wieki. 
go się z niepokojami na tle religijnym przede wszystkim za sprawą radykalnych protestanckich duchownych, którzy - jak napisal - za punkt honoru sobie poczytuja w sprzeczki $z$ Królami się wdawanie oraz zamętu $w$ królestwach catych powodowanie ${ }^{31}$. Podobnie jak jego oponenci sięgał więc do Biblii, formułując kontrargumentację na rzecz swojej pochodzącej wprost od Boga władzy, to teologia była bowiem przedmiotem jego szczególnego zainteresowania od najmłodszych lat.

Już w napisanym pięć lat przed śmiercią Elżbiety I The Trew Law of Free Monarchies Jakub dał szczegółowy i koherentny wykład doktryny boskiego prawa królów. Rozpoczyna swój wywód od przedstawienia celu, jaki przyświecał mu, kiedy pisał swoją rozprawę, nie pozostawiając przy tym czytelnikowi żadnych złudzeń: Nie ma zatem rzeczy równie ważnej, aby znali ją ludzie jakiegoś kraju, oprócz znajomości ich Boga, jak wtaściwa znajomość ich przynależności odpowiadająca sposobowi rzadów ustanowionemu nad nimi, w szczególności w [przypadku] monarchii (który to sposób rządów, przez podobieństwo do Boskiego, zbliża się najbardziej do doskonatości, jak wszyscy uczeni i roztropni mężowie od zawsze zgadzali się; jednośćstanowi doskonatość wszystkich rzeczy). Dlatego nieznajomość i (co jest jeszcze gorsze) zwiedzione przekonania wielu zaślepionych przez tych, którzy myślą, że sa zdolni nauczyć i wyszkolić nieświadomych, powodowaty rozktad i upadek rozmaitych rozwijajacych się rzeczypospolitych [Commonwealths] oraz mnóstwo wielkich niebezpieczeństw grożących zupetnym zniszczeniem innych. Uśmiechajacy się sukces, który w przesztości często zdarzat się bezprawnym buntownikom przeciwko ksiażętom (co byto wielkim nieszczęściem i niegodziwościa czasów), spowodowat w praktyce utwierdzenie wielu w ich btędzie, chociaż nie może istnieć bardziej zwodniczy argument niż ciagta ocena zasadności przyczyn takiego wydarzenia jak później zostanie [to] udowodnione w catości. I pośród innych żadna rzeczypospolita, która kiedykolwiek od zarania istniata, nie miata większej potrzeby prawdziwej wiedzy na ten temat aniżeli nasza od dawna nieuporzadkowana i rozproszona rzeczypospolita. Btędna wiedza na temat tego byta jedynie źródtem, $z$ którego wyptynęto tak wiele niekończacych się niebezpieczeństw, nieszczęśc i nieporozumień, co jest lepiej przez wielu odczuwane aniżeli dobrze znana i gtęboko przemyślana tego przyczyna. Dlatego naturalna gorliwość, która posiadam względem mojego rodzinnego kraju, [na który] muszępatrzé́ z ogromnym żalem ze względu na dtugie niepokoje spowodowane brakiem prawdziwej wiedzy na ten temat (jak jużpowiedziatem wcześniej), zmusita mnie wreszcie do przerwania milczenia, do podzielenia się niniejszym $z$ wami, moi drodzy rodacy, moim przekonaniem, $i \dot{z}$ [znam] przyczyny, z których wynikają wasze niekończące się ktopoty, jak również i to, że już zbyt dtugo kosztowaliście ich gorzki owoc, że możecie przy użyciu wiedzy uniknać przyczyn [i] uciec i odmienić optakane skutki, które zawsze bezpośrednio potem z konieczności następują ${ }^{32}$.

$\mathrm{Na}$ początku Jakub uzasadnić musi przede wszystkim boskie pochodzenie władzy i samej instytucji monarchii ${ }^{33}$. Tak jak jego oponenci posługuje się więc argumentem

31 Tamże, s. 49.

32 James VI (I), The Trew Law of Free Monarchies, [w:] The Political Works of James I, wstęp C.H. McIlwain, Cambridge 1918, s. 53-54, Harvard Political Classics, Vol. 1.

33 H. Inuzuka, Absolutism in the History of Political Thought. The Case of King James VI and I, „Political Science" 2007, Vol. 14, s. 206. 
z Pisma Świętego, bowiem monarchia wzorowana jest na boskości $i^{34}$. Sięga w tym celu do opisanych w Pierwszej Księdze Samuela (1 Sm 8) wydarzeń, kiedy Izraelici błagali Boga o to, by dał im króla ${ }^{35}$. Przytaczając cały fragment Biblii ${ }^{36}$, który określa charakter władzy monarszej, przypomina, że Stwórca ustami proroka ostrzegał ich, że wraz z ustanowieniem monarchii pojawią się nieznane wcześniej ciężary, prawem króla będzie bowiem rozkazywanie poddanym, czynienie $\mathrm{z}$ nich swych sług i żołnierzy, zagarnianie ich ziemi, zabieranie owoców ich pracy, nakładanie podatków. Pomimo tych ostrzeżeń, które miały przygotować ich serca i ręce do należnego postuszeństwa wobec Króla, którego miat im dać Bóg ${ }^{37}$, Izraelici dalej podtrzymywali swoją prośbę, odrzucając rady Samuela i wymuszając niejako na Bogu ustanowienie monarchii ze wszystkimi jej prerogaty-

34 James VI (I), The Trew Law..., s. 54.

35 Ten fragment Pisma Świętego był żywo dyskutowany i komentowany zarówno przez zwolenników, jak i przeciwników monarchii absolutnej, co ciekawe jednak jedni i drudzy wywodzili zeń wnioski zbieżne z własnym stanowiskiem, zob. J.P. Sommerville, English and European Political Ideas in the Early Seventeenth Century: Revisionism and the Case of Absolutism, „Journal of British Studies” 1996, Vol. 35, nr 2, s. 176-180. Por. przypis kolejny.

36 So Samuel tolde all the wordes of the Lord vnto the people that asked a King of him.

And he said, This shall be the maner of the King that shall raigne ouer you: he will take your sonnes, and appoint them to his Charets, and to be his horsemen, and some shall runne before his Charet. Also, hee will make them his captaines ouer thousands, and captaines ouer fifties, and to eare his ground, and to reape his haruest, and to make instruments of warre and the things that serue for his charels:

Hee will also take your daughters, and make them Apothicaries, and Cookes, and Bakers.

And hee will take your fields, and your vineyards, and your best Oliue trees, and giue them to his seruants.

And he will take the tenth of your seed, and of your Vineyards, and giue it to his Eunuches, and to his seruants.

And he will take your men seruants, and your maid-seruants, and the chiefe of your young men, and your asses, and put them to his worke.

He will take the tenth of your sheepe: and ye shall be his seruants.

And ye shall cry out at that day, because of your King, whom ye haue chosen you: and the Lord God will not heare you at that day.

But the people would not heare the voice of Samuel, but did say: Nay, but there shalbe a King ouer vs. And we also will be all like other Nations, and our King shall iudge vs, and goe out before vs, and fight our battles (1 Sm 8, 10-22).

Jakub nie cytuje przy tym znanej mu oczywiście Biblii Genewskiej, w której ten fragment ma zupełnie inny wydźwięk:

And he said, This will be the manner of the king that shall reign over you: He will take your sons, and appoint [them] for himself, for his chariots, and [to be] his horsemen; and [some] shall run before his chariots.

Not that kings have this authority by their office, but that such as reign in Gods wrath would usurp this over their brethren, contrary to the law (Deuteronomy 17:20).

And ye shall cry out in that day because of your king which ye shall have chosen you; and the LORD will not hear you in that day.

Because you do not repent for your sins, but because you long for your afflictions, into which you cast yourselves willingly.

W wydanej w 1611 roku Biblii Króla Jakuba fragment ten ma podobne brzmienie i przekaz jak przekład przytaczany w The Trew Law of Free Monarchies. 
wami. Wyboru króla nie dokonali więc, na co zwraca uwagę Jakub, sami Izraelici, lecz Bóg - czyniąc z Saula swego pomazańca, zatem tylko w Jego kompetencjach leży jego ocena i pozbawienie władzy. $Z$ casusu tego Jakub wyprowadza wniosek, że monarchia izraelska stanowi normatywny boski wzorzec dla monarchii chrześcijańskiej, określając relacje pomiędzy władcą a jego ludem. Monarcha jest więc niejako zewnętrzny wobec wspólnoty politycznej, nie wiążą go z nią żadne relacje o charakterze kontraktualnym, przeciwnie, węzeł zależności łączy go bezpośrednio z Bogiem, czyniąc z niego poniekąd bezpośredniego przedstawiciela Stwórcy na ziemi, z prerogatywami przypisywanymi tradycyjnie Jemu.

Odwołanie się przez Jakuba do tych, a nie innych przykładów ze Starego Testamentu dla wykazania charakteru swej władzy nie jest przypadkowe. Wiąże się bowiem z charakterystyczną cechą całego ruchu reformacyjnego, dla którego starotestamentowe argumenty na rzecz religijnej władzy monarchów były wygodnym uzasadnieniem odrzucenia papieskiego zwierzchnictwa religijnego i zanegowania jego władzy politycznej. Za panowania Dawida i Salomona uwielbienie Boga i bożej mądrości stały się bowiem bezpośrednio związane z królem i dworem, a protestanccy monarchowie chętnie przyjęli ten paradygmat, przyznając sobie rolę zwierzchników Kościołów narodowych. W ten sposób w niektórych państwach protestanckich (przede wszystkim w Anglii i Skandynawii) doszło do połączenia sfer świeckich i duchowych, a panujący został najwyższym autorytetem nie tylko w sprawach politycznych, ale i religijnych, odpowiedzialnym zarówno za doczesne, jak i duchowe potrzeby swoich poddanych. Oczywiście nie taki był początkowo zamiar reformatorów, którzy zwracając się do monarchów o pomoc, oczekiwali od nich jedynie wprowadzenia prawdziwej religii, a następnie podporządkowania się rządom bożym sprawowanym de facto przez duchownych ${ }^{38}$. Niemniej jednak Jakub zdawał sobie sprawę, o czym była mowa wcześniej, z zagrożeń dla swojej władzy wynikających z takiej perspektywy. Dlatego w jego argumentacji, wbrew opiniom głoszonym przez powracających z kontynentu kalwinów, ignorowane są wszelkie biblijne wątki negujące szczególną rolę monarchy i jego uprzywilejowaną pozycję w kontaktach z Bogiem, z których wynikać mogłyby ograniczenia jego władzy. Stąd z biblijnych argumentów Jakub wywodzi wniosek o immanentnym połączeniu władzy politycznej i kościelnej ${ }^{39}$. Szkocka Przysięga Supremacji wymagała bowiem od wszystkich szkockich duchownych, aby uznali go za jedynego prawowitego i najwyższego rzadce tego królestwa tak w sprawach doczesnych, jak i w pielegnowaniu i oczyszczeniu religii ${ }^{40}$. W 1584 roku Parlament szkocki uchwalił zaś Black Acts, które potępiły prezbiterian oraz stwierdzały władzę króla także w sprawach religijnych ${ }^{41}$. W opinii Jakuba

38 C. Cross, Churchmen and the Royal Supremacy, [w:] Church and Society in England. Henry VIII to James I, red. F. Heal, R. O’Day, Hamden 1977, s. 16.

39 J.P. Sommerville, James I and the Divine Right of Kings. English Politics and Continental Theory, [w:] The Mental World..., s. 55 i n.

40 Source Book of Scottish History, red. W.C. Dickinson, G. Donaldson, I.A. Milne, Vol. 3: From 1567 to 1707, London 1954, s. 12.

${ }^{41}$ J.G. Vos, The Scottish Covenanters. Their Origins, History and Distinctive Doctrines, Edinburgh 1995, s. 32 . 
to właśnie on, na wzór biblijnego Dawida, ma przewodzić swemu ludowi w wychwalaniu Boga i wypraszaniu u niego wszelkich łask ${ }^{42}$. Temu stanowisku dał także wyraz już na początku swego panowania w Anglii, podczas konferencji w Hampton Court. Postulaty purytańskich duchownych skwitował krótkim: No Bishop, no King, oraz niepozostawiającym wątpliwości komentarzem: Jeśli dążycie do tego samego co szkoccy prezbiterianie, to da się to pogodzićz $z$ Monarchia jak Boga i Diabta ${ }^{43}$. Chciał być więc, jak to określił, biskupem biskupów, powszechnym biskupem w swoim królestwie ${ }^{44}$. Cała władza urzędników, zarówno świeckich, jak i duchownych, pochodzić miała od niego, to on miał prawo mianować biskupów i wskazywać członków Sądu Wysokiej Komisji, by za ich pośrednictwem rządzić Kościołem Anglii. Pierwowzorami jego pozycji mieli być więc z jednej strony Dawid i Salomon, z drugiej zaś Konstantyn. W jego osobie, jako bożego namiestnika na ziemi, skupić miała się zatem cała władza, którą, niczym Bóg, nie dzielił się z nikim.

Owo przyrównanie władcy do Boga ma źródło również w zestawieniu ich atrybutów. Otóż Bóg ma prawo tworzenia i niszczenia, dawania życia i zsyłania śmierci, czynienia wszystkiego, czego zapragnie, osądzania wszystkiego i wszystkich, nie będąc przy tym za nic przed nikim odpowiedzialnym. W wyobrażeniu Jakuba bardzo podobna pozycja w państwie przysługuje monarchom. W Piśmie - pisze Stuart - Królowie nazywani sa Bogami, poprzez porównanie ich wtadzy z wtadza Boską ${ }^{45}$, bowiem moga oni stwarzać i niszczyć swych poddanych, maja wtadzę wywyższania i poniżania, prawo życia iśmierci, sądzenia we wszystkich przypadkach swych poddanych, nie odpowiadajac przed nikim, jak tylko przed Bogiem ${ }^{46}$. Nie ma przy tym różnicy pomiędzy chłopem, mieszczaninem i lordem. Każdy jest bowiem tak samo podległy swemu panu - królowi, który może nim dowolnie rozporządzać, jakby był należącą do niego rzeczą. Władca jest więc co prawda człowiekiem, lecz także matym Bogiem ${ }^{47}$, którego ustanowił Stwórca, by panowat nad innymi ludźmi ${ }^{48}$. Królowie - podkreśla Jakub - sa nazywani bogami przez prorokujacego króla Dawida, ponieważ zasiadaja za zezwoleniem Boga na Jego ziemskim Tronie i maja udziat w rządzeniu dany im ze względu na Niego ${ }^{49}$. Obowiązek posłuszeństwa ma w tej perspektywie charakter religijny, a bunt przeciw monarsze jest w rzeczy samej buntem przeciw samemu Bogu, którego władca jest ziemskim namiestnikiem.

Jakub, odpowiadając na argumenty radykalnych purytanów i monarchomachów, twierdzi więc, że skoro sam lud zgodził się na konsekwencje ustanowienia króla, a jego absolutna władza jest częścią danego przez Boga porządku, niedopuszczalny jest jaki-

42 James VI, A Meditation upon the xxv, xxvi, xxvii, xxviii and xxix verses of the XV Chapter of the First Booke of the Chronicles of the Kings, New York 1971, s. 84.

43 Appendix C. James and Puritans, [w:] The Political Works..., s. XC.

44 Cyt. za: P. Ha, English Presbyterianism, 1590-1640, Stanford 2011, s. 16.

45 Speech of 1609-1610, [w:] The Political Works..., s. 307.

46 Tamże, s. 308.

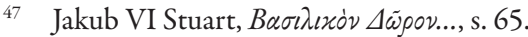

48 Tamże.

49 James VI (I), The Trew Law..., s. 54. 
kolwiek opór wobec jego władzy, nawet jeśliby zesłany przez Boga król był przekleństwem dla swego ludu. Brak posłuszeństwa w jakiejkolwiek kwestii czy w końcu jawny bunt są z tej perspektywy naruszeniem prawa Bożego wyrażonego na kartach Pisma Świętego. Teraz zatem - pisze Jakub - poczynając od tego Żydowskiego królestwa i monarchii, prawo to może i powinno być wzorem dla wszystkich Chrześcijańskich i prawidtowo stworzonych monarchii, skoro zostato ono ustanowione przez samego Boga, który przez swoja wyrocznię i wprost swoimi wtasnymi ustami nadat to prawo. Jaka wolność może [pozwolić] któtliwym duszom i buntowniczym umystom występować sprawiedliwie z żądaniami przeciwko jakiejkolwiek Chrześcijańskiej monarchii; ponieważ nie moga oni żadać większej wolności na swoją korzyść, niż lud Boga mógt czynić, i nigdy żadna większa tyrania nie byta sprawowana przez jakiegoś księcia czy tyrana, któremu można się sprzeciwić niz [ta, która] byta tutaj zapowiedziana ludowi Bożemu (i dotychczas wszystkie bunty byty odparte przeciwko nim) czy zadręczanie czyichś ludzi, synów, córek, stużby; nastawanie na szlachetne domy, mężczyzn i kobiet szlachetnej krwi, zniewalanie i podporzadkowywanie urzędów; i wydzieranie i tupienie ich ziem i dóbr dla prywatnego użytku $i$ wygody przez księcia i jego dworzan i stużących może być nazwane tyrania?

I ta propozycja oparta na Piśmie [Świętym] może dużo wyraźniej okazać się prawda. poprzez praktykę często udowadniana w tej samej księdze, [gdzie] nigdy nie czytamy, że jakiś prorok naktaniat ludzi do buntu przeciwko księciu, niezależnie, jak stabym by byt.

Kiedy Samuel za Bożym nakazem ogtosit królowi Saulowi, iż jego królestwo zostato mu odebrane i dane innemu (co w rezultacie byto ponizajace dla niego), jego kolejna czynnościa byta zmiana miejsca zamieszkania i zalana tzami modlitwa ku Bogu o nieco litości dla niego [tj. Saula].

I Dawid, pomimo że zostat osadzony $w$ tym samym upokarzajacym królewskim potożeniu, nie tylko (gdy zostat skazany okrutnie bez popetniania przestepstwa, lecz za dobra stużbę wobec niego) nie przypuszczat, że mając go w swej mocy, delikatnie, lecz z wielka powaga [może] dotknaćszaty namaszczonego przez Pana i w swych wtasnych stowach btogostawit go; jednakże gdy ktoś przybyt do niego i przechwalat się nieprawdziwie, że zabit Saula, on bez przeprowadzania procesu czy postępowania dotyczacego winy, powotujac się jedynie na zawinienie jego mowy, skazat go na śmierc ${ }^{50}$.

50 Tamże, s. 59-60. Dwa akapity dalej Jakub wyjaśnia absurdalność odwoływania się do biblijnych przykładów tyranobójstwa: I chociaż nigdy nie byto bardziej przerażajacego oprawcy i tyrana niż Achab, to jednak wszystkie bunty, które Eliasz kiedykolwiek wszczynat przeciwko niemu, polegaty na ucieczce na pustkowie, gdzie w celu przetrwania byt karmiony przez kruki. I wydaje mi się, że żaden cztowiek nie watpitby, iż Samuel, Dawid i Eliasz mieli wielka moc, aby przekonać ludzi, gdyby chcieli wykorzystać ich zaufanie, do [rozpętania] wrzawy czy buntu przeciwko stabym królom, tak jak w naszych czasach wielu naszych wywrotowych kaznodziejów różnych wyznań, czy to w tym kraju czy we Francji, skrzętnie zajmuje siępodburzaniem do buntu pod przykryciem religii. Dlatego tak dtugo jedynie mitość do prawdy [wywotuje] mój sprzeciw bez nienawiści wobec tych osób [i] zmusita mnie do bycia w pewien sposób prześmiewca. A jeśli ktoś będzie opierat się na nadzwyczajnych przypadkach usuwania albo zabijania królów [opisanych] w Piśmie [Świętym] w celu ostonięcia buntu ludzi, tak jak w przypadku czynu Jehu ipodobnych nadzwyczajnych [czynów] odpowiem, prócz tego, żechcąonimiećtakjakby zabezpieczenie, aby nadzwyczajne przyktady z Pisma [Świętego] mogty być wykorzystywane w codziennejpraktyce; powierzone morderstwo, jak w przypadku Ehuda i Jaeli; kradzież, jak w przypadku Izraelitów wychodzacych z Egiptu; ktamanie rodzicom w celu zranienia brata, jak w przypadku Jakuba, wszystkie [one] powinny być uznane 
Ta pozycja monarchy, jako stojącego poza i ponad wspólnotą polityczną, pozwala Jakubowi rozprawić się także z twierdzeniem Buchanana, jakoby to lud, a nie monarcha, był twórcą prawa. Z przytoczonej wyżej argumentacji wynika bowiem, że władca stoi ponad całym systemem prawnym i tak jak Bóg, do którego jest przyrównywany, włada całym światem, tak on w sposób arbitralny (lecz nie samowolny) włada swym królestwem, a Parlament, zwoływany sporadycznie, jest tylko najwyższym sadem królewskim $^{51}$. To królowie są jedynym źródłem prawa i wszystkich instytucji politycznych, byli, zanim poddani nabyli swą własność, zanim zwołano Parlamenty, zanim powstało prawo, zanim podzielono ziemię, zanim powstały stany, Stąd zatem należy wywieść, że to królowie byli twórcami i autorami Prawa, a nie Prawa twórcami królów, a król jest Dominus omnium abonorum i Dominus directus totus Dominij ${ }^{2}$.

Stuartowi nie była jednak obca idea praw fundamentalnych, która stanowiła jądro doktryny opozycji parlamentarnej, lecz rozumiał ją zupełnie inaczej niż jego oponenci, ograniczając ją jedynie, na wzór francuski ${ }^{53}$, do zasad sukcesji tronu. Common law - powiedział w parlamencie - jest ius Regis, i niczym więcej ${ }^{54}$. Widział więc siebie jako monarchę, którego nie więżą żadne normy prawa pozytywnego ${ }^{55}$. Król bowiem jest ponad prawem, zarówno jako jego autor, jak i dawca jego sity, i nic nie może go zmusić do jego przestrzegania, chyba że jego dobra wola lub dobry przyktad dawany poddanym ${ }^{56}$. To on określa więc zakres wolności poddanych, wolą swoją lub poprzedników. Wola poddanych zaś zawsze musi ulec jego opinii, nawet jeśli wyrażona byłaby w najbardziej autorytatywnej formie odwiecznego zwyczaju czy uroczystego akt parlamentu. Nie może co prawda w sprzeczności z prawem pozbawić swych poddanych życia, lecz prawo, zgodnie z którym to czyni, stanowione jest przez niego lub jego poprzedników, a zatem wtadza zawsze wyptywa z niego samego ${ }^{57}$. Ograniczeniem tej władzy nie jest nawet przysięga koronacyjna, nie oznacza ona bowiem poddania się jakiemukolwiek ziemskiemu autorytetowi, papieżowi, Kościołowi czy Parlamentowi ${ }^{58}$, lecz składana jest jedynie Bogu i tylko przed Nim władca ponosić będzie odpowiedzialność, ryzykując wtasna duszą $q^{59}$. Skoro jedynie Bóg ustanowił monarchów, dając im wyłączne prawo dokonywania sądów, to jedynie On, a nie nikt inny ma prawo ich samych poddać osądowi. Gdyby poddani

za zgodne z prawem i dopuszczalne cechy buntu przeciwko księciu. I żeby zakończyć, praktyka [opisana] w catym Piśmie [Świętym] potwierdza ludzkie postuszeństwo dane w wyroku prawa Bożego: Nie będziesz ztorzeczyt sędziemu, ani nie będziesz mówit źle o wtadcy twoich ludzi (tamże, s. 60).

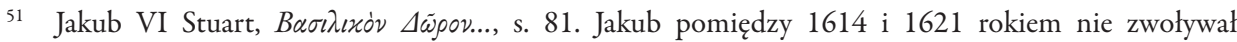
Parlamentu, co było najdłuższą przerwą od roku 1515. P. Croft, King James, s. 111.

James VI (I), The Trew Law..., s. 62.

53 J.W. Gough, Fundamental Law in English Constitutional History, Oxford 1955, s. 53.

54 Speech in Parliament in 1607, [w:] The Political Works..., s. 300.

55 C.H. McIlwain, The High Court of Parliament and its Supremacy. An Historical Essay on the Boundaries between Legislation and Adjudication in England, New Haven 1910, s. 75 i n.

56 James VI (I), The Trew Law..., s. 63.

57 Tamże.

58 A Defence to the Right of Kings, against Cardinal Perron, [w:] The Political Works..., s. 226.

59 James VI (I), The Trew Law..., s. 56. 
uzurpowali sobie to prawo, naraziliby państwo na niebezpieczeństwo rozpadu i anarchii. Już sam Paweł apostoł pouczał Rzymian, by dochowali posłuszeństwa Neronowi - krwawemu tyranowi, przeklensstwu owych czasów, potworowi, [...], batwochwalczemu prześladowcy ${ }^{60}$. Wszelka, nawet tyrańska władza zatem pochodzi wprost od Boga, a świętym obowiązkiem poddanych jest wierność i posłuszeństwo (z wyjątkiem sprzeciwu wobec samego Boga) wobec ich legalnego władcy jako bożego namiestnika na ziemi, miłość do niego jak do swego ojca i modlitwa. A gdy ten jest tyranem - cierpliwe znoszenie prześladowań, jak czynili to pierwsi chrześcijanie pod rządami pogańskich cezarów. Tak samo więc jak bluźnierstwem jest dyskusja o tym, czego może dokonać Bóg, tak zarozumiatościa i zniewaga ze strony Poddanych jest dyskusja o tym, co może uczynić Król, lub stwierdzenie, że Król nie może tego lub tamtego. Wszelkie tego rodzaju dyskusje muszą być zabronione, ponieważ, jak przekonuje Jakub, torują drogę do stabości Ksiązą i pozbawienia ich mistycznego szacunku należnego tym, którzy siedza na Tronie Boga ${ }^{61}$.

\section{III}

Uzasadnienie wywiedzione wprost z Biblii Jakub wzmacnia argumentem o charakterze patriarchalnym, niezwykle popularnym w owych czasach ${ }^{62}$. Zgodnie z prawem natury przekonuje - król staje się naturalnym ojcem dla wszystkich swoich wasali podczas swojej koronacji. I jako ojciec ze względu na swoje ojcowskie obowiazki jest zobowiązany dbać o wyżywienie, wychowanie i cnotliwe zarządzenie swymi dziećmi. Mimo wszystko król jest zobo-

60 Tamże, s. 60-61.

61 Speech in the Star Chamber, 1616, [w:] The Political Works..., s. 333.

62 Argument patriarchalny, który u Jakuba I Stuarta ma charakter posiłkowy i nie zostaje poddany wnikliwej analizie, stanowił fundament koncepcji największego XVII-wiecznego obrońcy boskich praw króla i absolutyzmu monarszego - Roberta Filmera. Wszelka wtadza na ziemi - pisze Filmer pochodzi od wtadzy ojcowskiej lub jest jej uzurpacja, nie ma bowiem innego fundamentu, na którym wznosi się wtadza. [...] Nawet wtadza, która sam Bóg sprawuje nad rodzajem ludzkim, jest wtadza ojcowska, jest on zarówno naszym Królem, jak i Ojcem (Directions for Obedience to Government in Dangerous or Doubtful Times, [w:] R. Filmer, Patriarcha and Other Political Works, red. P. Laslett, Oxford 1949, s. 233, Blackwell's Political Texts). Z założenia tego wyprowadza wniosek o absolutnym charakterze władzy królewskiej. Pochlebiamy sobie - twierdzi - mając nadzieje, że możemy być rzadzeni bez wtadzy arbitralnej. Nie, mylimy się: nie jest pytaniem, czy wtadza musi być arbitralna, lecz czy ma należeć do jednego czy wielu? Nigdy nie byto i nigdy nie będzie ludzi rządzonych bez arbitralnej wtadzy tworzenia praw, a każda wtadza tworząca prawo musi być arbitralna. [...] Jest uznane powszechnie, $\dot{z} e \mathrm{w}$ demokracji najwyższa $i$ arbitralna wtadza tworzenia prawa spoczywa $w$ ręku ttumu, podobnie $w$ arystokracji prawodawstwo lub wtadza arbitralna należy do niewielu lub do szlachty. I dlatego konieczna konsekwencja monarchii jest to, że wtadza tworzenia praw musi należeć do jednego, zgodnie $z$ zasadami Arystotelesa, który powiadat: Rząd należy do jednego, niewielu lub wielu (The Anarchy of a Limited or Mixed Monarchy, [w:] tamże, s. 286). Ostatecznie konkluduje, że 1. Nie ma formy rządu poza monarchia. 2. Nie ma innej monarchii jak tylko patriarchalna. 3. Nie ma monarchii patriarchalnej, która nie bytaby absolutna $i$ arbitralna. 4. Nie ma takich rzeczy jak arystokracja $i$ demokracja. 5. Ludzie nie rodza się z natury wolni (Observations on Mr. Hobbe's Leviathan or His Artificial Man. A Commonwealth, [w:] tamże, s. 229). 
wiąany troszczyćsię o wszystkich swoich poddanych. Gdy wszystkie prace i trudy, które ojciec może podjać dla swoich dzieci, będą uważane za lekkie i dobrze wyświadczone przez niego, wówczas skutek tego przyczyni się do ich [tj. poddanych - przyp. T.T.] zysku i bogactwa; dlatego ksiązępowinien czynić to wobec swoich ludzi. Tak jak rodzony ojciec powinien przewidzieć wszystkie trudności i niebezpieczeństwa, które moga powstać względem jego dzieci oraz mimo ryzyka dla swej wtasnej osoby [powinien] dażyć do tego samego, tak powinien król [czynić] wobec swoich ludzi. Jak ojcowski gniew i karcenie względem jakiegokolwiek jego dziecka, które uchybito powinno być ojcowskim napomnieniem wymierzonym z litościa, tak dtugo jak istnieje jakakolwiek nadzieja na [wynikającą] z nich poprawe, tak powinien król [czynić] wobec wszelkich swoich wasali, którzy uchybia w taki sposób. I wreszcie, tak jak ojcowska podstawowa radościa powinno być zabezpieczanie dobrobytu jego dzieci, radowanie się z ich pomyślności, smucenie się iżatowanie zich ztych [czynów], ryzykowanie dla ich bezpieczeństwa, pracowanie dla ich odpoczynku, czuwanie dla ich snu; ijednym stowem, myślenie, że ich ziemskie szczéście iżycie ustanowione jest i przeżywane bardziej dla nich niż dla siebie samego, tak powinien dobry książe myśleć o swoich ludziach ${ }^{63}$.

To patriarchalne spojrzenie na monarchię rodzi poważne konsekwencje, jeśli chodzi o relacje monarcha-poddani. Choć Jakub podkreśla w przytoczonym fragmencie obowiązki, jakie spoczywają na królu, to traktowanie poddanych jako jego dzieci determinuje jego absolutne władztwo, jakie dzierży nad nimi. Ich pierwowzorem jest dla Jakuba postać biblijnego Adama i jego synów, nad którymi pierwszy rodzic sprawował władzę absolutną i niczym nieograniczoną, oraz instytucje prawa rzymskiego. To prawo natury daje, zdaniem Jakuba, ojcom rodzin absolutną i arbitralną władzę nad ich dziećmi. Jest ona pierwowzorem władzy, jaką dzierżą monarchowie nad swymi ludami ${ }^{64}$. Z owej genetycznej ciągłości pomiędzy władzą pierwszego rodzica i władzą monarszą wynika nieograniczona władza króla nad swym rodem-ludem. Nie bez powodu bowiem, jak przekonuje Jakub, w Piśmie Świętym królowie porównywani są do Ojców rodzin, ponieważ Król jest w rzeczywistości Partens patriae, politycznym ojcem swego ludu ${ }^{65}$. Jeśli chodzi o Ojców rodzin - mówi dalej - byli oni wedle starodawnego Prawa Natury Patriam potestatem, które byto Potestatem vitae \& necis, wtaścicielami swych dzieci lub rodzin (mam tu na myśli Ojców rodzin, którzy byli w prostej linii przodkami rodzin, z których pierwotnie wywodzili się królowie:) [...]. Tak więc ojciec może dysponować swym dziedzictwem, wedle swego upodobania, ba, nawet wydziedziczyć najstarszego syna z jakiejkolwiek przyczyny i wybrać najmtodszego, zgodnie ze swym upodobaniem; uczynić ich żebrakami lub bogaczami dla swej przyjemności, uwięzić lub wygnać sprzed swego oblicza, jeśli znajdzie jakieś przewinienie, lub przywrócić ich znowu do task jak skruszonego grzesznika: W ten sam sposób może postępować Król ze swymi Poddanymi ${ }^{66}$.

Owo podleganie władzy ojca-króla ma więc źródło w prawie natury i naturalnym, powołanym do życia przez Boga porządku świata, gdyż każdy rodzi się zarówno sy-

\footnotetext{
63 James VI (I), The Trew Law..., s. 55-56.

64 Tamże, s. 65.

65 Speech of 1609-1610, s. 307.

66 Tamże, s. 308.
} 
nem, poddanym swego naturalnego rodzica, jak i poddanym władcy swego królestwa. Poucza nas o tym czwarte przykazanie, z którego wynika także to, że tak, jak winniśmy cześć ojcom prywatnych rodzin, tak wiele większa cześć winniśmy ojcu naszego kraju i catego królestwa ${ }^{67}$. To charakterystyczne dla patriarchalizmu przedstawianie struktury społecznej w kategoriach naturalnych, posiadających boską sankcję, było wtedy powszechnie akceptowane i używane w debacie politycznej ${ }^{68}$. Naturalna podległość członków rodu ojcu, jego władza nad nimi również dla wielu pisarzy była stanem oczywistym, mającym za sobą silne argumenty empiryczne. Dla przykładu w swym traktacie $A$ Godly Form of Household Government Robert Cleaver i John Dod przekonywali, że Pan domu nazywany jest Pater Familias, którym jest ojciec rodziny, ponieważ powinien sprawować ojcowska piecze nad swymi niewolnikami, jakimi sa jego dzieci. Wszystkich stug bożych należy w kilku stowach nauczać, że sq oni winni swym panom i paniom: mitość, przywiazanie, jakim odpowiedzialne dzieci darzq swych ojców $w^{69}$. Ów stosunek wynika wyłącznie z faktu ojcostwa i nie jest wspomagany przez inną okoliczność lub uzależniony od niej. W podobnym tonie wypowiadają się inni pisarze tego okresu, a wtórują im duchowni anglikańscy, czwarte przykazanie interpretujący jako konieczność posłuszeństwa ojcu ludu, tak jak ojcu rodziny. W 1614 roku ukazał się anonimowy katechizm definiujący rodziców jako naszych naturalnych Rodziców, ojców naszego Kraju, naszej dynastii i ojców w Chrystusie ${ }^{70}$. Robert Ram niespełna 40 lat później wyjaśnia zakres owego posłuszeństwa, które winniśmy: 1. Naszym naturalnym Rodzicom, Ojcom i Matkom. 2. Naszym Rodzicom Spotecznym, Zwierzchnikom, Rządzacym i catej wtadzy. 3. Naszym Ojcom Duchowym, Pastorom, Postom i Nauczycielom ${ }^{71}$. Stąd nie jest niczym zaskakującym, że w wydanym anonimowo w roku 1615 dziele God and the King, które królewskim dekretem miało być studiowane w szkołach i na uniwersytetach Anglii i Szkocji, autor pisze, iż Dowody, które podsuwa rozum, ucza, że silniejsza i wyższa więź obowiązku taczy dzieci z ojcem ich kraju niż z ojcem w prywatnej rodzinie ${ }^{72}$. I tak jak nie powinno się dyskutować z opinią ojca, tak nie wolno podawać w wątpliwość decyzji swego władcy. Gdyby poddani uzurpowali sobie to prawo, naraziliby państwo na niebezpieczeństwo rozpadu i anarchii.

Państwo bowiem, i tu Jakub I sięga do kolejnego argumentu, podobne jest do żywego organizmu, gdzie głowa decyduje o funkcjach wszystkich innych organów. Jakub, patrząc

${ }_{67}$ R. Mocket, God and the King, or, A Dialogue, Shewing That Our Soveraign Lord the King of England, Being Immediate under God within His Dominions, Doth Rightly Claim Whatsoever is Required by the Oath of Allegiance, London 1633, s. 35.

68 Zob. G.J. Schochet, The Authoritarian Family and Political Attitudes in 17th-Century England. Patriarchalism in Political Thought, New Brunswick 1988, s. 54 i n.; C. Hill, The Century Revolution, 1603-1714, Edinburgh 1961, s. 276 i n.

69 J. Dod, R. Cleaver, A Godly Form of Household Government, for the Ordering of Private Families, London 1598, sigs. Z5, Aa5.

70 Short Questions and Answeres, Contayning the Summe of Christian Religion, London 1614, sigs. B2v-B3.

71 R. Ram, The Countrymens Catechusme, or, A Helpe for Householders, London 1655, s. 39.

72 R. Mocket, God and the King..., s. 2. 
na państwo na typowo średniowieczną jeszcze modłę, widzi je wzorem Jana z Salisbury i Akwinaty jako dzieło człowieka, lecz byt naśladujący inne boskie kreacje, stworzone na podobieństwo ciała składającego się ze spełniających różne skoordynowane funkcje organów. Jego budowa opiera się na swoistym zhierarchizowanym porządku, w którym poszczególne części, choć zależne od siebie i koniecznie współegzystujące, przeznaczone są do pełnienia odmiennych celów. Brak u niego szczegółowej analizy tego zagadnienia, jakie znaleźć możemy choćby w Policraticusie, bowiem Jakub skupia się przede wszystkim na wykazaniu supremacji i nieodzowności absolutnej władzy panującego. Nie ma już u niego misternej średniowiecznej struktury, lecz pod wpływem Bodina pozostaje prosta relacja panujący-poddani. Poprzestaje więc jedynie na stwierdzeniu, że ciało królestwa sktada się z Gtowy i Ciata: Gtowa jest Król, Ciatem cztonkowie Parlamentu ${ }^{73}$. I o ile w średniowiecznych koncepcjach organicystycznych występuje silny pierwiastek deterministyczny, to dla Jakuba, akcentującego elementy wolicjonalne, to głowa, która ma wtadze kierowania wszystkimi cztonkami ciata ${ }^{74}$, czyli monarcha ${ }^{75}$, określa funkcje pełnione przez swych podanych. To on wyłącznie ocenia ich przydatność, nagradza i karze wedle swego uznania, od góry kreując porządek społeczny mocą swojej prerogatywy. Jeśli więc zestawimy to z przytoczonym wcześniej porównaniem króla i Boga, to władca jawi się nam jako swoisty kreator ziemskiego ładu politycznego. W swej mowie do parlamentu król ujął to w sposób sugestywny, lakoniczny i nieznoszący sprzeciwu: Jestem Mężem, a cata ta Wyspa jest moja prawna Żona. Jestem Gtowa, a to jest moje Ciato. Jestem Pasterzem, a to jest moje Stado ${ }^{76}$. Porównanie to jest tym silniejsze, jeśli zestawimy je z patriarchalnym uzasadnieniem władzy króla jako Pater familias ludu królestwa. Jakub nie ma przy tym wątpliwości, że to głowa jest najważniejszym organem ciała, Ponieważ z gtowy, będacej miejscem Osądu, wyptywa troska i przezorność kierowania i zapobiegania wszelkiemu ztu. Gtowa troszczy się o ciato, tak jak Król o swój lud. Jako że osąd wyptywa z gtowy, jako jedynej mogącej poruszać resztę cztonków, każdym zgodnie z jego funkcją, tak dtugo, jak sa do tego zdolne, tak podobnie, gdy któreś z nich dotknięte sa jakąśstabościa, musi dostarczyć im remedium w uleczalnym przypadku, a jeśli jest inaczej, powinna odcią je wobawie zainfekowania reszty; tak teżjest pomiędzy Księciem a jego ludem ${ }^{77}$. To powiązanie głowy i ciała skutkuje w ostatecznej konsekwencji tym, że glowa będzie musiata odciać zgnite $c z t o n k i^{78}$. Działanie takie, powróćmy jeszcze raz do pierwszego argumentu, ma bezpośrednią boską legitymację, gdyż zadaniem władców jest wymierzanie sprawiedliwości i karanie występnych w imieniu Stwórcy.

Kolejny argument, którego używa Jakub w The Trew Law of Free Monarchies dla udowodnienia swej absolutnej władzy, ma charakter historyczny, wywiedziony z pra-

\footnotetext{
73 Speech of 1605, [w:] The Political Works..., s. 287.

74 Speech of 1609-1610, s. 308.

75 I wreszcie, Królowie sa porównywani do gtowy tego Mikrokosmosu, jakim jest ciato cztowieka (tamże, s. 307).

76 Speech of 1605, s. 272.

77 James VI (I), The Trew Law..., s. 64-65.

78 Tamże, s. 66.
} 
wa podboju. Jest bowiem następcą tych, którzy pierwsi opanowali dziką i barbarzyńską jeszcze Szkocję: Dlatego, jak zaświadczaja nasze Kroniki, ta Wyspa, a w szczególności nasza jej część byta nieznacznie zamieszkata, przez niewielkq - lecz barbarzyńska i mato cywilizowana - liczbę [mieszkańców] i wtedy przybyt z Irlandii, która byta dtugo zamieszkata przed nami, nasz pierwszy Król Fergus, a w raz z nim wielka liczba [osadników], i uczynit się panem kraju poprzez swoja przyjaźń i sitę, jak również [z pomocą] Irlandczyków przybytych z nim, jak $i$ [z pomocą] mieszkańców kraju, którzy chętnie za nim podązyli, sam siebie uczynit Królem i Panem tak wszystkich ziem, jak i wszystkich, którzy je zamieszkuja. Pierwszy król sam utworzył królestwo na niecywilizowanej zie$\mathrm{mi}$, dał mu prawa i stworzył jego instytucje, jako pierwszy ustanowit państwo i forme rzadu, a później sam wydat prawa, a do tego [kolejne wydali] jego następcy ${ }^{79}$. Identyczne były historyczne początki innych królestw, także Anglii, do której przykładu sięga Jakub, wskazując, że Wilhelm Bastard, najeżdżając ją, prawem podboju ustanowił nowe prawa i nowe instytucje wedle swego uznania ${ }^{80}$. To zatem król jest właścicielem całej ziemi królestwa, która jest jego prywatną własnością, a której części mocą jego łaski rozdysponowane zostają między jego poddanych. W jego rękach spoczywa ostatecznie dominium $^{81}$ i imperium, bowiem jest oczywiste, że Król jest Wtaścicielem catości ziemi, tak samo jest Panem wszystkich Osób, które ją zamieszkują, dzierżąc wtadzężycia i śmierci nad nimi wszystkimi ${ }^{82}$.

\section{IV}

Wywód Jakuba nie koncentruje się jednak jedynie na uzasadnieniu boskiego prawa królów. W analogii do tej argumentacji znaleźć można w jego pismach bardzo rozbudowaną narrację dotyczącą obowiązków władcy chrześcijańskiego, sam zaś Baбılıxòv $\Delta \tilde{\omega}$ jov napisany dla syna jest przykładem literatury parenetycznej. Co istotne, wzorzec chrześcijańskiego władcy formułowany przez Stuarta jest konsekwencją przyjętych

79 Tamże, s. 62.

80

Dlatego, gdy bękart z Normandii przybyt do Anglii i uczynit sam siebie królem, czy nie odbyto się to bez sity i wielkiej armii? Dat prawa i niczego nie zabrat, zmienit prawo, odwrócit porzadek rzadzenia, obsadzit obcych będących jego zausznikami w komnatach wielu starych posiadtości, tak że dzis dobrze widać, że wielka czesść gentelmanów Anglii pochodzi z normańskiej krwi, a ich prawa, którymi po dziś dzień siępostuguja, sa zapisane w jego języku, a nie wich [tj. tubylców]. A jego następcy z wielką radościa cieszą się Korona po dziś dzień. Jak byto to uczynione przez tych wszystkich, którzy podbili ich wcześniej (tamże, s. 63).

81 Inazakończeniu tego punktu, żekróljest najwyższym wtadcąnad catympaństwem, jestpodobnie codziennie udowadniane przez prawo dotyczące naszych skarbów, przez żądania dziedziców i bękartów. Jeśli bowiem skarb zostanie znaleziony pod powierzchnia ziemi, ze względu na fakt, że nie jest on w posiadaniu albo użytku jakiejś osoby, zgodnie z prawem należy do króla. Jeśli osoba umrze bez jakichkolwiek dziedziców, wówczas wszystkie jej ziemie i dobra powracają do króla. I jeśli nieuznany bękart umrze bez dziedziców „ze swojego ciata” (których uznanie spoczywa jedynie w rękach króla), wszystko, co miat, podobnie powraca do króla i jak widzimy jest to oczywiste, że Król jest najwyższym wtadca w catym państwie (tamże).

Tamże. 
przezeń fundamentów jego legitymacji oraz zakresu władzy. Z każdego argumentu na rzecz boskiego prawa królów wynikają odpowiednie zalecenia kierowane w stronę boskiego pomazańca. Podobne jest ich uzasadnienie odwołujące się do przykładów z Pisma, argumentów patriarchalnych i organicystycznych ${ }^{83}$. Pisze zatem o królach, że Ich urzad jest [ustanowiony] aby zarządzać sprawiedliwościa i wydawać wyroki ludziom, jak ten sam Dawid powiedziat. Aby wynagradzać dobro i karać zto, jak również powiedziat. Aby ustanowić dobre prawa swoim ludziom i zapewniać ich przestrzeganie, jak czynili to różni dobrzy królowie Judy. Aby zapewnić pokój ludziom, jak ten sam Dawid powiedziat. Aby rozpatrywać wszystkie spory, które moga powstać między nimi, jak czynit Salomon. Aby być szafarzem Boga dla dobra tych, którzy czynia dobro, i szafarzem Boga, aby zemścićsię na tych, którzy czynią zto, jak św. Pawetpowiedziat. I na końcu jako dobry pasterz, co wychodzi na zewnątrz i przed swój lud, jak jest powiedziane w Pierwszej Księdze Samuela. Że ze względu na pomyślność Księcia może być zapewniony pokój między ludźmi, jak mówi Jeremiasz. I dlatego, pisze dalej, podczas koronacji naszych wtasnych królów, jak również wszystkich chrześcijańskich monarchów, sktadają oni przysiege, po pierwsze zachowywania religii obecnie wyznawanej w catym kraju, zgodnie zjej prawami, gdziekolwiek jest to ustanowione, i karania tych wszystkich, którzy mogliby naciskać na [jej] zmianę albo zaktócać jej wyznawanie. I następnie zachowywać wszystkie chwalebne i dobre prawa wydane przez ich poprzedników oraz czuwać nad ich wykonywaniem, a tamiacych i przekraczajacych je ukarać zgodnie z ich wtasnym brzmieniem. I wreszcie dbać o caty kraj i każda jego część, o ich starożytne przywileje i wolności, jak również [chronić] przed obcymi wrogami, jak również przed wewnętrznymi. I wreszcie zapewnić dobro i rozkwit jego ludzi, nie tylko poprzez zachowywanie i czuwanie nad wykonywaniem dawnych chwalebnych praw kraju i poprzez ustanawianie nowych (gdy koniecznośc i zte zwyczaje będa [tego] wymagaty), ale za pomoca wszelkich innych sposobów umożliwiajacych przewidzenie i uniknięcie wszelkich niebezpieczeństw, które moga im się przydarzyć oraz zachować harmonię, bogactwo i ogtadę wśród nich, jako kochajacy ojciec i ostrożny stróż, czyniący dla nich więcej niż dla siebie samego, wiedzacy, że jest ustanowiony dla nich, a nie oni dla niego ${ }^{84}$.

Widzimy więc, że kryterium oceny władcy jest klasyczna kategoria salus populi, dzięki której Jakub dokonuje w średniowiecznym jeszcze duchu analizy i przeciwstawienia monarchy i tyrana. Pierwszy z nich zaprzęga cały swój talent i umiejętności, by dawać ludowi dobre prawa i zapewnić mu pokój i dobrobyt, dobro ogótu jako nadrzędna swą powinność zawsze na względzie mając. Konsekwencją władzy otrzymanej wprost od Boga jest więc obowiązek zabiegania o dobro wspólnoty ${ }^{85}$. Tyran tymczasem całą energię i działania skupia na zaspokojeniu swych ambitnych pretensji ${ }^{86}$. By zatem uznać władcę za sprawiedliwego, wystarczy jego posłuch wobec prawa boskiego i naturalnego oraz

\footnotetext{
83 Inieużteczna - mówi Stuart - bytaby gtowa, gdyby zamiast lekarstwa aplikowata truciznę lub puszczata krew, co spowodować mogtoby ciężka dolegliwość lub nawet zniszczenie (Speech of 1609-1610, s. 309). James VI (I), The Trew Law..., s. 55.

85 H. Inuzuka, Absolutism in the History of..., s. 208.

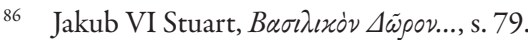


przestrzeganie przez niego moralnego zobowiązania do troski o dobro poddanych. Czy nie pozostaje to jednak w sprzeczności z tym, co powiedziane było wcześniej, i czy jednak władca, by nie zostać uznanym za tyrana, przestrzegać musi nie tylko starodawnych praw królestwa i szanować uświęcone swą dawnością prawa i wolności poddanych, ale i normy wykreowane przez niego samego ${ }^{87}$ ? Pytanie to jest tym bardziej zasadne, gdy

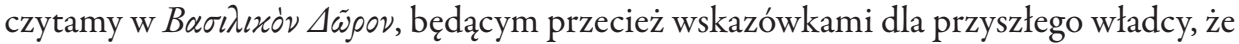
w kraju naszym więcej Praw dobrych już mamy, niźli egzekwujemy. Przeto nalegam jedynie, byś w rzadach swych ich egzekwowania przestrzegat ${ }^{88}$.

Na pierwszy rzut oka, i wynika to z wcześniejszych wywodów, obowiązek taki, jako bożego pomazańca, władcy nie wiąże. Jako boży porucznik związany jest tylko wolą Stwórcy i lekceważyć może wszelkie ziemskie normy. Ta oczywista konkluzja poddana być musi jednak zasadniczej rewizji, skażona jest bowiem już czysto nowożytną koncepcją suwerenności rodem z dzieł Hobbesa i częściowo wywodów Bodinusa. Dochodzimy w tym miejscu do fundamentalnej dla określenia pozycji monarchy kwestii, jaką jest rozróżnienie abstrakcyjnych i konkretnych prerogatyw króla. To, o czym do tej pory była mowa, w zamyśle samego Jakuba definiuje potencjalne, wynikające wprost $\mathrm{z}$ boskiej legitymacji i na poły boskiego statusu władcy, uprawnienia. In potentia król ma więc, o czym już wspomniano, władzę wywyższania i poniżania, życia i śmierci, sadzenia wszystkich swych podanych i wszystkich spraw, odkąd zostat wybrany nie przez kogo innego, lecz przez Boga samego ${ }^{89}$. Z drugiej jednak strony, na co Jakub wskazuje w tej samej mowie do Parlamentu: Lecz gdybym byt na jego miejscu, dodatbym jedynie dwa stowa, które by wszystko wyjaśnity. Po tym bowiem, co powiedziat o Boskości, [i] co byto w ogólności nakazane poddanym wobec ich królów, wówczas bym zakończyt jak Anglik, ukazujac ludziom, że co do zasady wszyscy poddani sa zobowiązani znosić swego Króla. Zatem aby napomnieć ich, że żyjemy w konkretnym Królestwie, które jest zarządzane przez jego wtasne fundamentalne prawa $i$ zwyczaje, że po to zostali oni teraz (zebrani w tym celu $w$ Parlamencie), aby rozważý, jak pomóc takiemu Królowi, jakiego teraz mają. I dlatego ze względu na tę dawna formutę $i$ zwyczaje ustalone w tym Królestwie wyraża się różnica pomiędzy ogólnymi uprawnieniami Króla w Boskości i określonym i ustalonym stanem tej Korony i Królestwa. Co więcej, konkluduje swój wywód Jakub, Każdy Król w konkretnym Królestwie jest zobowiazany, by przestrzegać paktu, jaki zawart ze swym ludem przez jego Prawa $a^{90}$, na wzór tego, jaki Bóg zawarł z Noem po zakończeniu potopu ${ }^{91}$. Król musi rządzić zgodnie z ustalonymi prawami królestwa ${ }^{92}$,

87 Twierdził tak potem Filmer, dla którego nie istnieje nic takiego, jak tyrania: Prawda niezbicie dowodzi, $\dot{z}$ e zamej natury rzeczy niemożliwa jest taka forma rządu, której celem bytoby zniszczenie ludu, jak to przypisuje się tyranii; jeśli więc chcemy rządzić ludem, musimy to przyznać, musi być on po pierwsze zachowany, inaczej nie będziemy mieli kim rzadzić (Observatios on Mr. Milton Against Salmasius, [w:] R. Filmer, Patriarcha..., s. 259).

Speech of 1609-1610, s. 308.

Tamże.

Tamże, s. 309.

J.W. Gough, Fundamental Law..., s. 53. 
świat bowiem został stworzony nie tylko dla królów, lecz także dla ich poddanych. Poddani nie są więc jego niewolnikami, a absolutny monarcha nie jest w rzeczywistości niczym niezwiązany. By zachować i chronić prawo, sam musi je respektować, choć z jego szczególnej roli wynikać musi możliwość jego przekraczania w sytuacjach nadzwyczajnych, o czym poucza tradycja angielskiej monarchii. Nie jest to jednak nielegalne, ponieważ salus rei publicae was suprema lex. W tym samym przemówieniu Jakub zapewnił, że wielkim szacunkiem darzy common law i przedkłada je nad wszelkimi prawami, nawet prawem Mojżesza, ponieważ dobro i pomyślność królestwa jest dla niego najważniejszą wartością, która to deklaracja wywołała entuzjazm wśród członków Parlamentu ${ }^{93}$.

Ta pozorna sprzeczność daje się wyjaśnić, jeśli, podążając na Jakubem, dokonamy demarkacji argumentu teologicznego i polityki. W średniowiecznej refleksji politycznej polityka bez wątpienia zdominowana była przez teologię, była swoistym przedłużeniem jej rozważań i konkluzji. Choć w Jakubowym myśleniu pozostaje pewien refleks owego paradygmatu, to mamy u niego bez wątpienia do czynienia ze swoistym rozdzieleniem tych dwóch sfer, które jednak pozostają w genetycznej symbiozie. Pozwala się to wyjaśnić, jeśli zdamy sobie sprawę z celu, jakiemu służyła teoria boskiego prawa królów w wiekach XVI i XVII. Była ona bowiem przede wszystkim orężem w walce przeciwko politycznym aspiracjom papiestwa, później przeciwko żądaniom prezbiterian czy w końcu teoriom kontraktualistycznym. Ich punktem wspólnym było zaś ograniczenie władzy monarszej, a w radykalnych wersjach uzasadnienie buntu czy nawet tyranobójstwa ${ }^{94}$. Boskie pochodzenie władzy monarszej miało więc neutralizować, będące podstawą wspomnianych teorii, twierdzenie o pochodzeniu władzy od ludu. Skupiało się przede wszystkim na obowiązku posłuszeństwa, by spacyfikować te wywrotowe z punktu widzenia Stuarta doktryny. Z pewnością jednak teoria Jakuba nie była wymierzona $\mathrm{w}$ angielski konstytucjonalizm i koncepcję praw fundamentalnych, zwłaszcza że Jakub zgodził się, by prerogatywa poddana została kontroli sądów, a te potwierdziły praktyczne konsekwencje stanowiska Jakuba ${ }^{95}$.

Pewne absolutystyczne wątki nie miały więc w tym kontekście zasadniczego znaczenia, co wyraźnie podkreślił Jakub w cytowanej przed momentem mowie. Jeśli więc mówić można o absolutyzmie, to tylko jako konsekwencji boskiego pomazania, a i to w wymiarze przede wszystkim deklaratoryjnym i sferze mitologicznej. Absolutna władza de facto nie była bowiem potrzebna dla osiągnięcia celu, jaki stawiali sobie król Szkocji i Anglii oraz inni zwolennicy podobnych teorii. I choć konsekwencją boskiego prawa królów mógł być absolutyzm, to jego nowożytna postać wywodzi się z zupełnie innych,

93 Proceedings in Parliament, 1610, Vol. 1, red. E.R. Foster, New Haven 1966, s. 55, Yale Historical Publications. Manuscripts and Edited Texts, 22-23.

94 Sam Jakub dbał przy tym, by jego przemówienia w Parlamencie, w których wykładał swą doktrynę władzy, były drukowane i szeroko rozpowszechniane w Królestwie (M. Mondi, The Speeches and Self-Fashioning of King James VI and I to the English Parliament, 1604-1624, "Constructing the Past” 2007, Vol. 8, nr 1, s. 140).

95 J.R. Tanner, English Constitutional Conflicts of the Seventeenth Century, 1603-1689, Cambridge 1928, s. 36 . 
przed wszystkim romanistycznych, źródeł ${ }^{96}$. Odróżnia ona bowiem monarchę od tyrana przede wszystkim za pomocą kategorii moralnych ${ }^{97}$, a nie konstytucyjnych. Jakub tymczasem wprost odwołuje się do tych ostatnich, wskazując ostatecznie obowiązek przestrzegania przez władcę praw fundamentalnych. Na poziomie teologicznym jest władcą absolutnym, na poziomie politycznym jednak trudno wyrazić o nim tak kategoryczną opinię. Do prawdziwego absolutyzmu ${ }^{98}$ konieczna jest bowiem koncepcja suwerenności, zgodnie z którą władza posiada możliwość wiązania prawem wszystkich poddanych, sama nie będąc nim związana. Absolutny monarcha miał przede wszystkim rządzić dobrze, by uniknąć oskarżenia o tyranię, paradoksalnie zaś monarcha Jakuba w sposób konstytucyjny. Takie uzasadnienie władzy nie stanowiło więc zagrożenia dla konstytucji i rządów prawa ${ }^{99}$. Równocześnie, o czym rzadko się pamięta, niosło z sobą istotny ładunek teologiczny i moralny, kładąc wielki nacisk na obowiązki wobec Boga zarówno władcy, jak i jego poddanych. To podleganie prawom boskim, co tak podkreślał Jakub, w rzeczywistości także stanowiło ograniczenie suwerenności, to ono bowiem było podstawą hierarchii społecznej, z której monarchowie wywodzili swą władzę $e^{100}$.

\section{KONKLUZJE}

Jeśli przyjmiemy taki punkt widzenia, staje się jasne, dlaczego mowy Jakuba wygłoszone do angielskiego Parlamentu, obok podkreślania boskiego pochodzenia jego władzy, są nastawione pokojowo i pokazują go jako godnego zaufania i lojalnego wobec poddanych władcę ${ }^{101}$. Nie są więc zatem, moim zdaniem, jedynie wyrazem dążenia do kom-

96 F. Oakley, Jacobean Political Theology..., s. 329-330. gdy suwerenność catkowicie spoczywa w osobie króla, którego wtadza nie może być poddana prawnym ograniczeniom. Cate prawo jest zaledwie ustęstwem jego woli $i$ wszystkie konstytucyjne formy i zgromadzenia uzaleznione sa od jego uznania (J.N. Figgis, The Theory..., s. 5-6).

99 G. Burgess, Common Law and Political Theory in Early Stuart England, „Political Science” 1988, Vol. 40, nr 1, s. 4-17; P. Christianson, Royal and Parliamentary Voices on the Ancient Constitution, c. 1604-1621, [w:] The Mental World..., s. 71-95.

100 J. Daly, Cosmic Harmony and Political Thinking in Early Stuart England, Philadelphia 1979, s. 21-31, Transactions of the American Philosophical Society, Vol. 69, pt. 7.

101 Tymczasem Jakub opinię absolutysty zawdzięcza przede wszystkim XVIII-wiecznej wigowskiej historiografii, która kazała patrzeć na niego i jego następców jak na tyranów gwałcących starożytną angielską konstytucję (P. Croft, King James, s. 4). W tym ujęciu jego koncepcja władzy była nie do pogodzenia ze stanowiskiem parlamentarnej opozycji pod przywództwem Coke’a (C.H. Mcllwain, The High Court..., s. 347-348; por. również: R.G. Usher, James I and Sir Edward Coke, „The English Historical Review" 1903, Vol. 18, nr 72, s. 664-675). Jeśli jednak przyjrzymy się bliżej temu problemowi i porównamy praktykę Tudorów i Stuartów, dostrzeżemy, że ci ostatni korzystali ze swej prerogatywy w bardziej powściągliwy sposób niż ich poprzednicy na angielskim tronie (por. G.R. Elton, Henry VIII's Act of Proclamations, „The English Historical Review” 1960, Vol. 75, nr 295, s. 208-222; M.L. Bush, The Act of Proclamations. A Reinterpretation, „The American Journal of Legal History" 1983, Vol.27, nr 1, s. 33-53). Adwokatem swego ucznia może być również sam Bodin, który 
promisu, lecz wpisują się w teoretyczne ramy jego filozofii politycznej. Filozofii, która łączy w sobie elementy tradycji i nowego, renesansowego spojrzenia na politykę. $Z$ jednej strony bowiem, co podkreśla Jakub, jego władza pochodzi wprost od Boga i związany jest on prawem boskim oraz, na co zwrócić należy szczególną uwagę, konstytucją królestwa, lecz z drugiej strony, co bez wątpienia jest owocem lektury Bodina, to król jest wyłącznym prawodawcą. Sześć ksią o Rzeczypospolitej wywarło wielki wpływ na refleksje Jakuba, lecz zawarte w nich tezy i wnioski istotnie odbiegają od jego stanowiska $^{102}$. Nie idzie więc Jakub tak daleko jak Bodin, który ostatecznie wiąże władzę jedynie prawami Boga i natury, czyniąc ją suwerenną: Majestat est summa nn cives Ac subditos legibusque soluta potestas - nie tylko na poziomie legitymacji, lecz przede wszystkim praktyki z perspektywy prawnika, a jedynym, i to iluzorycznym, ograniczeniem władzy pozostaje obowiązek prawego rządzenia ${ }^{103}$, zwłaszcza gdy zdamy sobie sprawę z konsekwencji stanowiska Bodina, zgodnie z którym jest duża różnica między prawem [le droit], a ustawa [la loy]: pierwsze zawiera tylko stuszność, ustawa zawiera rozkaz; albowiem ustawa nie jest niczym innym, jak rozkazem suwerena uzywajacego swej wtadzy ${ }^{104}$. Zatem ostatecznie podstawą porządku prawnego jest rozkaz suwerena zabezpieczony przymusem. Nie interesuje go również kwestia pochodzenia władzy i ogranicza się jedynie do stwierdzenia, że król przez analogię do swych prerogatyw jest wizerunkiem Boga, podczas gdy Jakub odwołuje się do starej tradycji, w której król jest ziemskim namiestnikiem Stwórcy, z którym łączą go szczególne relacje, a jego władza ma mistyczny charakter. Związanie monarchy prawem boskim jest tu immanentnie połączone z podstawami jego legitymacji. Pochodzenie władzy od Boga zajmuje więc centralne miejsce w argumentacji Jakuba, podczas gdy Bodin zagadnienie to właściwie pomija ${ }^{105}$, ograniczając się do stwierdzenia faktu jej suwerenności. Z tego wynika w koncepcji Stuarta równoległe obowiązywanie prawa Boga i natury oraz prawa pozytywnego, które z nich czerpie swą moc obowiązującą, podczas gdy u Bodina te pierwsze pozostają jedynie wskazówkami prawodawczymi. Ostatecznym celem Jakuba była realizacja starego ideału monarchii chrześcijańskiej, w której teologiczny komponent jest nieodzowny, u Bodina zaś Bóg występuje jedynie jako figura perswazyjna, a jego koncepcja uwolniona zostaje całkowicie niemal od presji teologii. Paradoksalnie więc Jakub próbuje dokonać zabiegu przeciwnego zamiarom Bodina i uczynić jego koncepcję władzy i suwerenności substancjalnie chrześcijańską, ze wszystkimi tego konsekwencjami. Nie może zatem

- będąc dobrze poinformowany w angielskich stosunkach - stwierdził, że suwerenność należy do królów Anglii w catości (J. Bodin, Sześć ksiag o Rzeczypospolitej, I, VIII, wstęp. Z. Izdebski, Warszawa 1958, s. 118).

102 Z pewnością jednak podobna była geneza obu koncepcji, a mianowicie zapobieżenie wojnie domowej. Podczas gdy Jakub atakował katolików i prezbiterian, Bodin dał odpowiedź hugenockim monarchomachom (J.H. Franklin, Jean Bodin and the Rise of Absolutist Theory, Cambridge 1973, s. 41, Cambridge Studies in the History and Theory of Politics).

103 J. Bodin, Sześć ksiag..., I.I, s. 11-12.

104 Tamże, I, VIII, s. 139.

105 J. Jellinek, Ogólna nauka o państwie, ks. 2-3, przeł. M. Balsigierowa, M. Przedborski, Warszawa 1924, s. 323. 
być zwolennikiem religijnej ambiwalencji władzy, która jest przecież strażnikiem jedynej prawdziwej religii ${ }^{106}$, gdy tymczasem Bodin uwalnia państwo od takiej roli, otwierając drogę do tolerancji religijnej ${ }^{107}$. Tym samym jednak przyspiesza proces ostatecznej desakralizacji władzy i sekularyzacji polityki, który ostatecznie doprowadzić musi do powstania absolutnego i nieliczącego się z niczym państwa, czego Jakub z pewnością nie pragną. W końcu zacytujmy Locke’a, nieprzejednanego wroga tyrańskiej władzy, który o Jakubie, komentując jego mowy do Parlamentu, wypowiedział się w sposób następujący: Tak to ten uczony król, który dobrze rozumiat istotę rzeczy, oddaje różnicę między królem a tyranem sprowadzająca się tylko do tego, iż jeden traktuje prawa jako granice swej wtadzy, a dobro publiczne jako cel swych rzadów, drugi zaśs sprawuje ja, aby uczynić zadość swej woli i zaspokoić wtasne zachcianki ${ }^{108}$.

\section{BIBLIOGRAFIA}

Andrew E., Jean Bodin on Sovereignty, „Republics of Letters. A Journal for the Study of Knowledge, Politics, and the Arts" 2011, Vol. 2, nr 2.

Bingham C., The Making of a King. The Early Years of James VI and I, Garden City, N.Y. 1968. Bodin J., Sześć ksiag o Rzeczypospolitej, I, VIII, wstęp Z. Izdebski, Warszawa 1958.

Buchanan G., De Jure Regni Apud Scotos, or, A Dialogue, Concerning the Due Privilege of Government, in the Kingdom of Scotland, Betwixt George Buchanan and Thomas Maitland, Philadephia 1766.

Buchanan G., A Dialogue on the Law of Kingship Among the Scots. De Jure Regni Apud Scotos Dialogus, przet. i red. M.S. Smith, R.A. Mason, wstęp R.A. Mason, Edinburgh 2006, St. Andrews Studies in Reformation History.

Burgess G., Common Law and Political Theory in Early Stuart England, „Political Science” 1988, Vol. 40, nr 1.

Burgess G., Festenstein M. (red.), English Radicalism, 1550-1850, Cambridge-New York 2007. Bush M.L., The Act of Proclamations. A Reinterpretation, „The American Journal of Legal History" 1983, Vol. 27, nr 1.

Croft P., King James, New York 2003.

Daly J., Cosmic Harmony and Political Thinking in Early Stuart England, Philadelphia 1979, Transactions of the American Philosophical Society, Vol. 69, pt. 7.

Dickinson W.C., Donaldson G., Milne I.A. (red.), Source Book of Scottish History, Vol. 3: From 1567 to 1707, London 1954.

Dod J., Cleaver R., A Godly Form of Household Government, for the Ordering of Private Families, London 1598.

Dunning W.A., Jean Bodin on Sovereignty, „Political Science Quarterly” 1896, Vol. 11, nr 1.

106 H.J. Laski, The Political Ideas of James I, „Political Science Quarterly” 1919, Vol. 34, nr 2, s. 298.

107 E. Andrew, Jean Bodin on Sovereignty, „Republics of Letters. A Journal for the Study of Knowledge, Politics, and the Arts" 2011, Vol. 2, nr 2, s. 76.

108 J. Locke, Dwa traktaty o rządzie, II, §200, przeł. Z.Rau, Warszawa 1992, s. 306. 
Elazar D.J., Kincaid J. (red.), The Covenant Connection. From Federal Theology to Modern Federalism, Lanham 2000.

Elton G.R., Henry VIII's Act of Proclamations, „The English Historical Review” 1960, Vol. 75, nr 295.

Figgis J.N., The Theory of the Divine Right of Kings, Cambridge 1896, Cambridge Historical Essays, $\mathrm{nr} 9$.

Filmer R., Patriarcha and Other Political Works, red. P. Laslett, Oxford 1949, Blackwell's Political Texts.

Foster E.R. (red.), Proceedings in Parliament, 1610, New Haven 1966, Yale Historical Publications. Manuscripts and Edited Texts, 22-23.

Franklin J.H., Jean Bodin and the Rise of Absolutist Theory, Cambridge 1973, Cambridge Studies in the History and Theory of Politics.

Geneva Bible, London 1955.

Gough J.W., Fundamental Law in English Constitutional History, Oxford 1955.

Greenleaf W.H., James I and the Divine Right of Kings', „Political Studies” 1957, Vol. 5, nr 1.

Ha P., English Presbyterianism, 1590-1640, Stanford 2011.

Heal F., O'Day R. (red.), Church and Society in England. Henry VIII to James I, Hamden 1977.

Hill C., The Century Revolution, 1603-1714, Edinburgh 1961.

Hill C., The World Turned Upside Down. Radical Ideas during the English Revolution, London 1973.

Inuzuka H., Absolutism in the History of Political Thought. The Case of King James VI and I, „Political Science" 2007, Vol. 14.

James VI, A Meditation upon the xxv, xxvi, xxvii, xxviii and xxix verses of the XV Chapter of the First Booke of the Chronicles of the Kings, New York 1971.

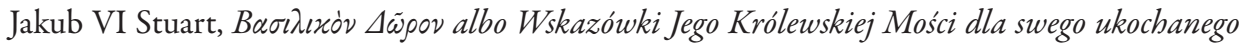
syna Henryka, księcia, wstęp, przeł. i oprac. M. Misztal, Kraków 2006, Literatura Parenetycznaprzez Wieki.

Jellinek J., Ogólna nauka o państwie, ks. 2-3, przeł. M. Balsigierowa, M. Przedborski, Warszawa 1924.

Knox J., History of the Reformation in Scotland, Glasgow 1841.

Knox J., On Rebellion, red. R.A. Mason, Cambridge-New York 1994, Cambridge Texts in the History of Political Thought.

Laski H.J., The Political Ideas of James I, „Political Science Quarterly” 1919, Vol. 34, nr 2.

Lee M. Jr., Great Britain's Solomon. James VI and I in His Three Kingdoms, Urbana 1990.

Locke J., Dwa traktaty o rządzie, przeł., wstęp i koment. Z. Rau, Warszawa 1992, Biblioteka Klasyków Filozofii.

M'Crie T., John Knox. Containing Illustrations of the History of the Reformation in Scotland, Edinburgh 1831.

Mason R.A. (red.), Scots and Britons. Scottish Political Thought and the Union of 1603, Cambridge 1994.

McFarlane I.D., Buchanan, London 1981.

McIlwain C.H., The High Court of Parliament and its Supremacy. An Historical Essay on the Boundaries between Legislation and Adjudication in England, New Haven 1910. 
Mocket R., God and the King, or, A Dialogue, Shewing That Our Soveraign Lord the King of England, Being Immediate under God within His Dominions, Doth Rightly Claim Whatsoever is Required by the Oath of Allegiance, London 1633.

Mondi M., The Speeches and Self-Fashioning of King James VI and I to the English Parliament, 1604-1624, „Constructing the Past” 2007, Vol. 8, nr 1.

Morgan E.S. (red.), Puritan Political Ideas, 1558-1794, Indianapolis 2003.

Mullan D.G., Scottish Puritanism, 1590-1638, Oxford-New York 2000.

Oakley F., Jacobean Political Theology. The Absolute and Ordinary Powers of the King, „Journal of the History of Ideas" 1968, Vol. 29, nr 3.

Peck L.L. (red.), The Mental World of the Jacobean Court, Cambridge-New York 1991.

The Political Works of James I, wstęp C.H. McIlwain, Cambridge 1918, Harvard Political Classics, Vol. 1.

Ponet J., A Short Treatise on Political Power, and of the True Obedience which Subjects our to Kings and Other Civil Governors, with an Exhortation to All True and Natural English Men (reprint), New York 1972.

Ram R., The Countrymens Catechusme, or, A Helpe for Householders, London 1655.

Salmon J.H.M., Renaissance and Revolt. Essays in the Intellectual and Social History of Early Modern France, Cambridge 2003.

Schochet G.J., The Authoritarian Family and Political Attitudes in 17th-Century England. Patriarchalism in Political Thought, New Brunswick 1988.

Scott J.B., The Catholic Conception of International Law. Francisco de Vitoria, Founder of the Modern Law of Nations, Francisco Suárez, Founder of the Modern Philosophy of Law in General and in Particular of the Law of Nations. A Critical Examination and a Justified Appreciation, Washington D.C. 1934.

Short Questions and Answeres, Contayning the Summe of Christian Religion, London 1614.

Skinner Q., The Foundations of Modern Political Thought, Vol. 2: The Age of Reformation, Cambridge 1978.

Sommerville J.P., English and European Political Ideas in the Early Seventeenth Century. Revisionism and the Case of Absolutism, „Journal of British Studies” 1996, Vol. $35, \mathrm{nr} 2$.

Szlachta B., Konstytucjonalizm czy absolutyzm? Szkice z francuskiej myśli politycznej XVI wieku, Kraków 2005, Biblioteka Myśli Politycznej - Ośrodek Myśli Politycznej, 43.

Tanner J.R., English Constitutional Conflicts of the Seventeenth Century, 1603-1689, Cambridge 1928.

Usher R.G., James I and Sir Edward Coke, „The English Historical Review” 1903, Vol. 18, nr 72. Vos J.G., The Scottish Covenanters. Their Origins, History and Distinctive Doctrines, Edinburgh 1995.

Dr hab. Tomasz TULEJSKI, prof. UŁ- profesor nadzwyczajny w Katedrze Doktryn Polityczno-Prawnych na Wydziale Prawa i Administracji Uniwersytetu Eódzkiego oraz współpracownik Centrum Myśli Polityczno-Prawnej im. Alexisa de Tocqueville’a. Autor m.in.: Od zasady użyteczności do demokracji. Filozofia polityczna Jeremy Benthama i Konserwatyzm bez Boga. Dawida Huméa wizja spoteczeństwa, państwa i prawa. 